\title{
Accelerated Alpha Radiation Damage in a Ceramic Waste Form, Interim Results
}

By:

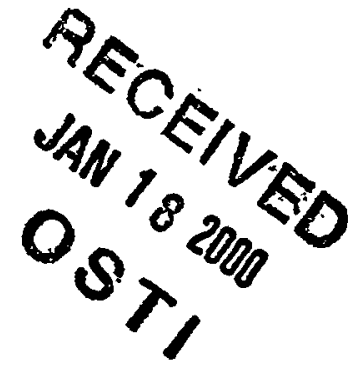

S.M. Frank, S.G. Johnson, T.L. Moschetti, T.P.O'Holleran, W. Sinkler, D. Esh, and K.M. Goff

Nuclear Technology Division

Argonne National Laboratory

P. O. Box 2528

Idaho Falls, ID 83403-2528

\begin{abstract}
The submitted manuscript has been created by the University of Chicago as Operator of by the University of Chicago as ("Argonne") Argonne National Laboratory (Argonne under Contract No. W-31-109-ENG-38 with the U.S. Department of Energy. The U.S. Government retains for itself, and others acting on its behalf, a paid-up, nonexclusive. ing on lis berle worldwide license in said article irrevocable worldwide license in said article to reproduce, prepare derivative works, distribute copies to the public, and perform publicly and display publicly, by or on behalf of the Government.
\end{abstract}

Materials Research Society

Scientific Basis for Waste Management XXIII .

Boston, MA

November 29-December 3, 1999

*Work supported by the U. S. Department of Energy, Office of Nuclear Energy, Science and Technology, and the Office of Environmental Management, under contract W-31-109-Eng-38. 


\section{DISCLAIMER}

This report was prepared as an account of work sponsored by an agency of the United States Government. Neither the United States Government nor any agency thereof, nor any of their employees, make any warranty, express or implied, or assumes any legal liability or responsibility for the accuracy, completeness, or usefulness of any information, apparatus, product, or process disclosed, or represents that its use would not infringe privately owned rights. Reference herein to any specific commercial product, process, or service by trade name, trademark, manufacturer, or otherwise does not necessarily constitute or imply its endorsement, recommendation, or favoring by the United States Government or any agency thereof. The views and opinions of authors expressed herein do not necessarily state or reflect those of the United States Government or any agency thereof. 


\section{DISCLAIMER}

Portions of this document may be illegible in electronic image products. Images are produced from the best available original document. 


\section{ACCELERATED ALPHA RADIATION DAMAGE IN A CERAMUC WASTE FORM, INTERIM RESULTS}

Steven M. Frank, Stephen G. Johnson, Tanya L. Moschetti, Thomas P. O'Holleran, Wharton Sinkler, David Esh, K. Michael Goff, Argonne National Laboratory-West

P.O. Box 2528

Idaho Falls, Idaho 83403-2528

\section{ABSTRACT}

Interim results are presented on the alpha-decay damage study of $\mathrm{a}^{238} \mathrm{Pu}$-loaded ceramic waste form (CWF). The waste form was developed to immobilize fission products and transuranic species accumulated from the electrometallurgical treatment of spent nuclear fuel. To evaluate the effects of $\alpha$-decay damage on the waste form, the ${ }^{238} \mathrm{Pu}$-loaded material was analyzed by 1 ) $x$-ray diffraction (XRD), 2) microstructure characterization by scanning electron microscopy (SEM) and transmission electron microscopy (TEM) with energy and wavelength dispersive spectroscopy (EDS/WDS) and electron diffraction, 3) bulk density measurements and 4) waste form durability, performed by the product consistency test (PCT). While the predominate phase of plutonium in the $\mathrm{CWF}, \mathrm{PuO}_{2}$, shows the expected unit cell expansion due to $\alpha$-decay damage, currently no significant change has occurred to the macro- or microstructure of the material. The major phase of the waste form is sodalite and contains very little $\mathrm{Pu}$, although the exact amount is unknown. Interestingly, measurement of the sodalite phase unit cell is also showing very slight expansion; again, presumably form $\alpha$-decay damage.

\section{INTRODUCTION}

The ceramic waste form (CWF) used for this study was developed to immobilize fission products and actinide materials that accumulate during the electrometallurgical treatment of spent nuclear fuel at Argonne National Laboratory in Idaho in support of the ANL/DOE Spent Fuel Demonstration Project [1]. Fission products and transuranic actinides concentrate in a molten, $\mathrm{LiCl}-\mathrm{KCl}$ eutectic salt during electrometallurgical treatment of spent fuel. The contaminated eutectic salt is removed from the electrorefiner and processed into the CWF for final disposal in a geological repository. The waste form produced during fuel conditioning will contain roughly 0.2 weight percent $\mathrm{Pu}$, primarily of ${ }^{239} \mathrm{Pu}$ isotopic composition. Of regulatory interest to the repository is the waste form behavior [2]. To investigate potential, long-term behavior of alpha-decay damage on the actual CWF, but in a much shorter period, tests were initiated using a CWF containing surrogate fission products and ${ }^{238} \mathrm{Pu}$ as opposed to ${ }^{239} \mathrm{Pu}$. The use of ${ }^{238} \mathrm{Pu}$, with its high specific activity of $6.3 \times 10^{13}$ decays/min $\mathrm{g}$ and half-life of 88 years, allows significant $\alpha$-decay dose in a matter of years as opposed to thousands of years in the case of ${ }^{239} \mathrm{Pu}$. Thus the term accelerated alpha damage. The data presented concludes the first year of a four-year study. The current accumulated alpha decay dose is approximately $5 \times 10^{17} \alpha-$ decays/gram of material. The total accumulated dose at the end of the four-year study will be approximately $2 \times 10^{18} \alpha$-decays/gram of material.

Many literature reviews have been compiled on radiation damage to materials [3] In particular, $\alpha$-decay studies of crystalline materials or glass materials containing actinide host phases reveal that the crystalline material may become amorphous due to accumulation of dislocated matrix atoms $[4,5]$. Amorphization of crystalline phases leads to volume increases that may in turn lead to microcracking. Swelling and cracking of the material usually have detrimental effects on the performance of the waste form [6]. After prolonged exposure, He or 
other gas bubbles may develop. However, some cryställine materials, such as $\mathrm{PuO}_{2}, \mathrm{UO}_{2}$ and $\mathrm{ZrO}_{2}$ for example, show little damage to the crystalline structure after prolonged radiation exposure[3]. This study wishes to address these issues relating to the CWF.

\section{EXPERIMENTAL}

A detailed description of the processing of the CWF is found elsewhere [7]. The process first involves occluding the salt in dry ( $<0.5 \mathrm{wt} \%$ moisture) zeolite $4 \mathrm{~A}$. The zeolite is then mixed with a glass binder and consolidated at a temperature of $1100 \mathrm{~K}$ and a pressure of $34 \mathrm{MPa}$. During this processing, the zeolite converts to sodalite. The composition of the pre-processed mixture is shown in Table 1. The fission product surrogate salt contains $\mathrm{KBr}, \mathrm{KI}$ and the chlorides of $\mathrm{Na}, \mathrm{Rb}, \mathrm{Sr}, \mathrm{Y}, \mathrm{Cs}, \mathrm{Ba}, \mathrm{La}, \mathrm{Ce}, \mathrm{Pr}, \mathrm{Nd}, \mathrm{Sm}$ and $\mathrm{Pu}$. In this study, the CWF was loaded to approximately $2.5 \mathrm{wt} \%{ }^{238} \mathrm{Pu}$. This Pu loading is roughly 3 to 20 times the actual $\mathrm{Pu}$ (elemental) loading of the CWF produced during the fuel treatment process. As indicated in Table 2, Pu in the eutectic salt is in the chloride form. After contacting with the zeolite, the Pu converts to the oxide. This reaction is presumably due to the reaction with oxygen from residual water in the zeolite.

Table 1. Weight percent of each component in the pre-processed mixture.

\begin{tabular}{|c|c|c|c|c|c|}
\hline Component & $\begin{array}{c}\text { LiCl/KCl } \\
\text { Eutectic Salt }\end{array}$ & $\begin{array}{c}\text { Fission Product - } \\
\text { Surrogate Salt }\end{array}$ & Zeolite 4A & Glass binder & $\begin{array}{c}\text { Elemental } \\
\mathrm{Pu}\end{array}$ \\
\hline Weight \% & 4.1 & 1.7 & 64.7 & 25.0 & 2.5 \\
\hline
\end{tabular}

The ${ }^{238} \mathrm{Pu}$-loaded CWF is being analyzed on a periodic basis to evaluate $\alpha$-decay damage to the waste form. The testing schedule is planned for a minimum of 4 years. The methods used to study the extent of $\alpha$-decay damage on the CWF are separated into the following sections:

1) Waste form microstructure and elemental distribution is being investigated by scanning electron microscopy (SEM) in conjunction with energy and wavelength dispersive spectroscopy (EDS/WDS). Transmission electron microscopy (TEM), in conjunction with electron diffraction (ED) and EDS, is also being performed.

2) Powder $X$-ray diffraction (XRD) is used to monitor bulk phase composition and changes to major phase lattice parameters.

3) Density measurements on the CWF are being performed by an immersion method. Density measurements provide information on macroscopic swelling as a function of cumulative dose.

4) Durability of the ${ }^{238} \mathrm{Pu}$-loaded CWF, with cumulated $\alpha$-decay dose, is compared to the nonradioactive CWF reference material using the PCT-A leach method [8]. The leach test uses a crushed material with a -100 to +200 mesh size fraction, demineralized water for the leachant, and a surface area to volume ratio of $2000 \mathrm{~m}^{-1}$. Elemental determination of the leachate is performed by inductively coupled plasma-mass spectrometry.

\section{RESULTS}

\section{MICROSCOPY}

The microstructure (Figures $1 \mathrm{a}$ and $\mathrm{b}$ ) of the ${ }^{238} \mathrm{Pu}$-loaded CWF is very similar to the reference (non-Pu loaded) CWF and consists of 5 to 20 -micron diameter sodalite grains surrounded by the glass binder. Plutonium is found primarily as $\mathrm{PuO}_{2}$ in the glass intergranular boundaries between sodalite grains. Figure la shows the microstructure shortly after the material was produced. Figure $1 \mathrm{~b}$ shows the microstructure after one year of accumulated alpha damage. As can be seen, the two micrographs are indistinguishable with no visible indication of $\alpha$-decay 
effects. A second Pu containing phase has been identified by TEM as a tetragonal aluminosilicate material (Figure 2). This tetragonal phase has not been observed in the CWF containing $0.2 \mathrm{wt} \% \mathrm{Pu}$ and its presence is possibly due to the greater $\mathrm{Pu}$ loading used in this study. In addition, a strongly faceted, needle-like structure containing $\mathrm{Pu}$ has been observed as shown in Figure 2.
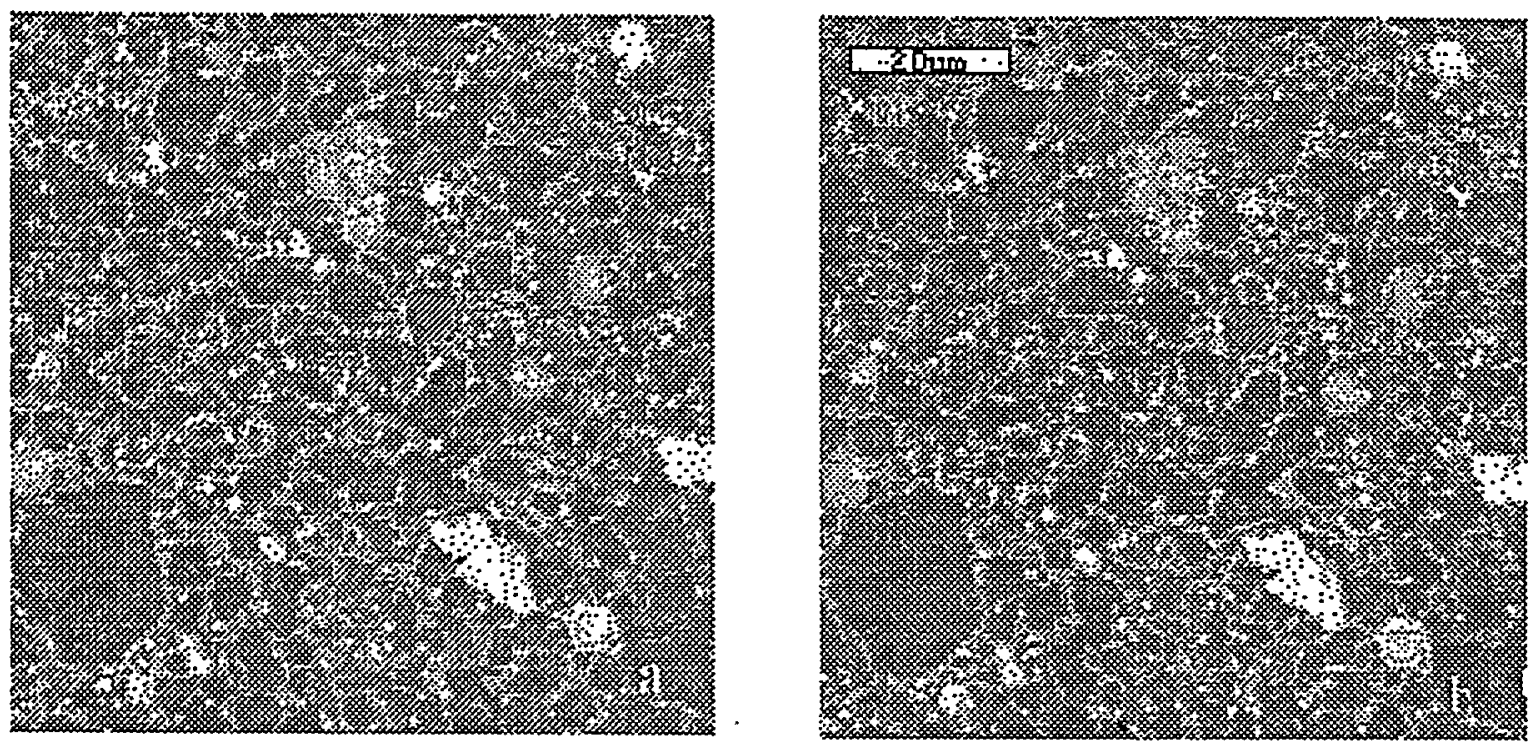

Figure 1. a) Back scattered electron image of ${ }^{238} \mathrm{Pu}$-loaded CWF shortly after the material was prepared. This image is considered representative of the overall sample. Brightest regions are $\mathrm{PuO}_{2}$, darkest regions are sodalite, medium dark regions are glass, and medium light regions are high Pu aluminosilicate. b) Same sample region after approximately one year $\left(5 \times 10^{17} \alpha-\right.$ decay/g) dose accumulation.

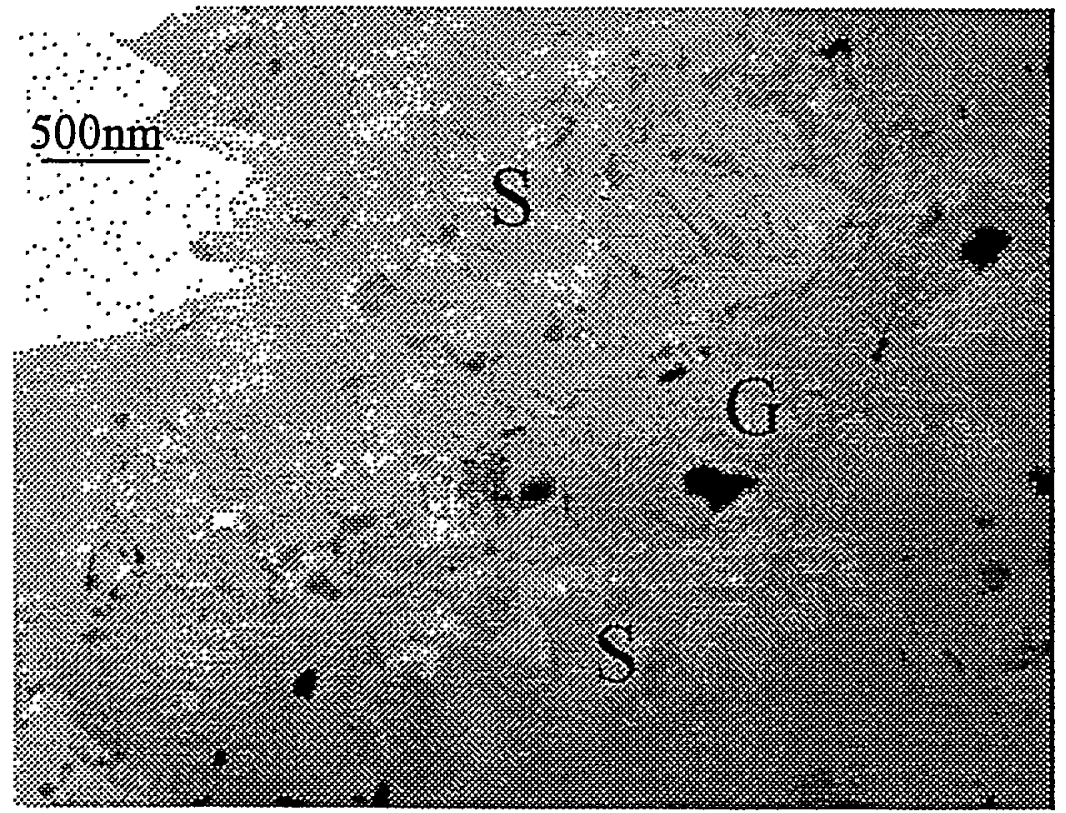

Figure 2. Low-magnification bright field image showing typical microstructure of ${ }^{238} \mathrm{Pu}$-loaded CWF. The two main phases are labeled S: sodalite phase and G: glass phase. Plutonium containing phases are seen as the dark objects. These include $\mathrm{PuO}_{2}$ fluoride structures, tetragonal $\mathrm{Pu}$ aluminosilicates and the strongly faceted, needle-like, Pu-containing material observed in the upper right of the micrograph. 


\section{X-RAY DIFFRACTION}

The waste form is comprised of four crystalline components as indicated by $\mathrm{x}$-ray diffraction. The weight percent of the four crystalline phases is shown in Table 3 and compares well with the reference (non-Pu loaded) CWF. The amorphous content of the sample was measured to be 22 percent, which corresponds to the target quantity of added glass binder of 25 weight percent within experimental uncertainty. The plutonium containing aluminosilicate and high $\mathrm{Pu}$ containing sodalite phases observed by TEM are not observed by XRD, probably due to the low relative amounts of the phases present in the waste form. Regardless the majority of the $\mathrm{Pu}$ is in the oxide form.

Table 3. Crystalline phase composition of ceramic waste form in weight percent. $\mathrm{LaB}_{6}$ was added to the sample as an internal standard for refinement purposes.

\begin{tabular}{|l|c|c|c|c|c|}
\hline Crystalline Phase & $\begin{array}{c}\text { Sodalite } \\
\mathrm{Na}_{4}\left(\mathrm{AlSiO}_{4}\right)_{3} \mathrm{Cl}\end{array}$ & $\mathrm{PuO}_{2}$ & $\begin{array}{c}\text { Nepheline } \\
\mathrm{NaAlSiO}_{4}\end{array}$ & $\begin{array}{c}\mathrm{Halite} \\
\mathrm{NaCl}\end{array}$ & $\begin{array}{c}\mathrm{LaB}_{6} \\
\mathrm{NIST} \mathrm{SRM} \\
660\end{array}$ \\
\hline $\begin{array}{l}\text { Crystalline Weight } \\
\text { Percent found in Waste } \\
\text { Form }\end{array}$ & 84 & 3 & 7 & 3 & 3 \\
\hline
\end{tabular}

$\mathrm{X}$-ray diffraction patterns were acquired from the ${ }^{238} \mathrm{Pu}$-loaded sample on days $2,21,72$, $97,146,240$ and 365 from the time the pellet was produced. For structural refinement, the $\mathrm{LaB}_{6}$ standard was used to determine instrumental constants. The $\mathrm{LaB}_{6}$ standard is not expected to sustain damage from radiation so the lattice parameter should not change with time. The average $\mathrm{LaB}_{6}$ lattice parameter value of $0.415695 \pm 0.000006 \mathrm{~nm}$ and matches very well with the NIST certified value. This excellent agreement of the measured lattice parameter of the $\mathrm{LaB}_{6}$ standard to the NIST certified value adds confidence to the measured lattice parameters of $\mathrm{PuO}_{2}$ and sodalite found in the sample. After pattern refinement, the lattice parameters of $\mathrm{PuO}_{2}$ and sodalite were compared to previous determinations. Unit cell expansion of the $\mathrm{PuO}_{2}$ phase is clearly shown in Figure 3 and has reached saturation with, to date, an overall expansion of $0.6 \%$. The self-irradiation saturation level for $\mathrm{PuO}_{2}$ appears to occur after approximately 100 days. This expansion is less than the $1 \%$ volume expansion that has been reported elsewhere [3] but may be due to initial crystal imperfections. The unit-cell expansion of $\mathrm{PuO}_{2}$ follows a profile observed by other investigators [9]. The authors of ref. [9] have postulated that the maximum results from a supersaturation of defects in the lattice followed by a lattice dilation due to defect migration to sink regions. After the decrease in lattice parameter, the expansion will increase gradually with the in-growth of ${ }^{234} \mathrm{UO}_{2}$ in the solid solution at a rate of $\Delta \mathrm{a}=+0.00045 \AA /$ year [10]. In the case of the sodalite phase, a unit-cell expansion with time response similar to $\mathrm{PuO}_{2}$ is possibly observed (also shown in Figure 3 ). This expansion of approximately $0.1 \%$ is questioned, however, considering the small quantity of $\mathrm{Pu}$ in that phase, as determined by microscopy, and the greater uncertainty in the sodalite lattice parameter measurement.

\section{Density Measurements}

The density of a ${ }^{238} \mathrm{Pu}$-loaded CWF sample has remained unchanged during the testing period to date. The density of the ${ }^{238} \mathrm{Pu}$-loaded CWF, as determined by immersion in water, is $2.42 \pm 0.01 \mathrm{~g} / \mathrm{cm}^{3}$. This density compares to an average density of $2.35 \pm 0.02 \mathrm{~g} / \mathrm{cm}^{3}$ for non-Pu CWF HIP material. The higher density of the ${ }^{238} \mathrm{Pu}$-loaded CWF is attributed to the high $\mathrm{Pu}$ loading in the sample. Increase in density of the sample provides the most direct evidence of 
volume expansion due to $\alpha$-decay damage, yet as mentioned none has been obsierved at the dose level of $5 \times 10^{17} \alpha$-decays/gram of material.

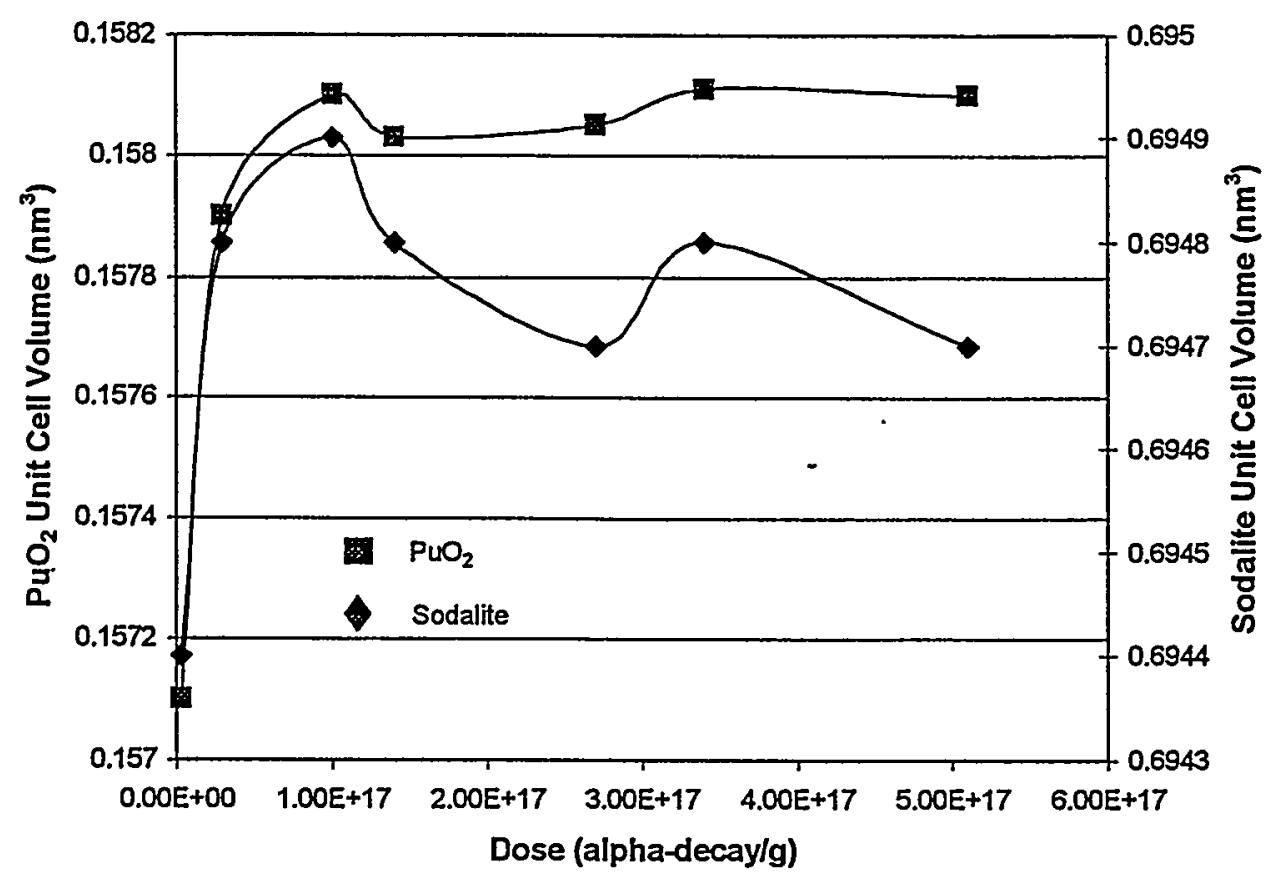

Figure 2. Unit cell volume change over time of $\mathrm{PuO}_{2}$ (a) and (b) sodalite in CWF.

\section{Durability Testing}

Short-term, PCT-A durability tests performed on the ${ }^{238} \mathrm{Pu}$-loaded CWF, and the results are shown in Table 4. The PCT is used to evaluate any changes in the dissolution behavior of the $\mathrm{CWF}$ with time as a result of $\alpha$-decay damage. These results from the first PCT, determined shortly after the material was produced, indicate that the ${ }^{238} \mathrm{Pu}$-loaded CWF degrades in a manner similar the reference (non-Pu loaded) CWF and other high level waste forms for the elements measured [11, 12]. The exception to this is the greater than expected release of Cs from the ${ }^{238} \mathrm{Pu}$-loaded waste form, for which no current explanation exists. Two more PCT analyses will be performed on similar material that was produced at the same time as the material tested in Table 4 to determine degradation in durability after increased dose accumulation.

Table 4. Normalized elemental release in $\mathrm{g} / \mathrm{m}^{2}$ from a PCT (7-day) leachate solution of Pu-238 loaded CWF. The normalized release is the average value of triplicate tests. Also shown are the uncertainties associated with instrumental analysis.

\begin{tabular}{|l|l|l|l|l|c|}
\hline Element & $\begin{array}{l}\text { Normalized } \\
\text { Release } \\
\left(\mathrm{g} / \mathrm{m}^{2}\right)\end{array}$ & $\begin{array}{l}\text { Relative } \\
\text { Uncertainty } \\
( \pm 1 \sigma) \text { (percent) }\end{array}$ & Element & $\begin{array}{l}\text { Normalized } \\
\text { Release } \\
\left(\mathrm{g} / \mathrm{m}^{2}\right)\end{array}$ & $\begin{array}{l}\text { Relative } \\
\text { Uncertainty } \\
( \pm 1 \sigma) \text { (percent) }\end{array}$ \\
\hline $\mathrm{Li}$ & 0.439 & 10 & $\mathrm{Al}$ & 0.035 & 10 \\
\hline $\mathrm{K}$ & 0.090 & 80 & $\mathrm{Ce}$ & 0.001 & 30 \\
\hline $\mathrm{Rb}$ & 0.165 & 10 & $\mathrm{Nd}$ & 0.001 & 20 \\
\hline $\mathrm{Cs}$ & 0.148 & 10 & $\mathrm{Pu}-238$ & 0.001 & 25 \\
\hline $\mathrm{Sr}$ & 0.016 & 40 & $\mathrm{Cl}$ & 0.376 & 10 \\
\hline $\mathrm{Ba}$ & 0.009 & 25 & $\mathrm{Br}$ & 1.79 & 70 \\
\hline $\mathrm{B}$ & 0.228 & 10 & & & \\
\hline
\end{tabular}




\section{CONCLUSIONS}

The results of the first year of cumulated alpha-decay damage to the CWF indicate no microscopic or macroscopic alteration to the waste form as a whole. Only the $\mathrm{PuO}_{2}$ phase has shown the expected unit cell volume increase resulting from lattice defects induced by alpha decay. The sodalite unit cell may also be expanding, but to much less extent than the $\mathrm{PuO}_{2}$ phase. Because $\mathrm{Pu}$ is primarily concentrated to the intergranular glassy regions, the majority of decay damage is expected to occur locally in these regions. Due to the concentration of $\mathrm{Pu}$ in the radiation damage resistant $\mathrm{PuO}_{2}$ fluorite structure, very little $\alpha$-decay damage to the waste form as a whole is expected. The one exception to this may be the formation and accumulation of $\mathrm{He}$ bubbles resulting from alpha decay. Bubble formation would most likely accumulate in the intergranular regions as well and may be a source for swelling. The greatest magnification of such swelling may be in an increase of elemental release rates (decrease material durability) observed during leach testing. Interim results from bulk density measurements, which have remained constant, and waste form durability, which has performed similar to the reference $\mathrm{CWF}$, indicate no adverse effects of alpha radiation damage to the waste form at an $\alpha$-decay dose of $5 \times 10^{17}$ decays/gram of material.

\section{REFERENCES}

1. J.P. Ackerman, S.M. McDeavitt, C. Pereira, L.J. Simpson, ANS Proceedings "Third Topical Meeting DOE Spent Nuclear Fuel and Fissile Materials Management", Charleston, SC, 699 (1998).

2. Office of Civilian Radioactive Waste Management, Waste Acceptance System Requirements Document, E00000000-00811-1708-00001, rev. 2 (1996).

3. W.J.'Weber,R.C. Ewing, C.R.A. Catlow, T. Diaz de la Rubia, L.W. Hobbs, C. Kinoshita, Hj. Matzke, A.T. Motta, M. Nastasi, E.K.H. Salje, E.R. Vance, S.J. Zinkle, J. Mater. Res., Vol. 13, pp.1432-1484 (1998).

4. R.C. Ewing, W.J. Weber, F.W. Clinard, Jr., Prog. Nucl. Energy 29 (2), 63 (1995).

5. K.A. Boult, J.T. Dalton, J.P. Evans, A.R. Hall, A.J. Inns. J.A.C. Marples, E.L. Paige, The preparation of fully active synroc and its radiation stability-Final Report, Oct. 1988. AERER-13318 (Harwell Laboratory, Harwell, UK, 1988).

6. A.G. Solomah, H. Matzke, Scientific Basis for Nuclear Waste Management XII, W. Lutze, R.C. Ewing, Eds., Mat. Res. Soc. Symp. Proc., Vol. 127, pp. 241-249 (1989).

7. S.M. Frank, D.W. Esh S.G. Johnson, M.H. Noy and T.P. O'Holleran, "Production and Characterization of a Plutonium-238 Loaded Ceramic Waste Form for the Study of the Effects of Alpha Decay Damage," to be published in Scientific Basis for Waste Management XXII, Edited by D.J. Wronkiewicz, Materials Research Society (1999).

8. ASTM C1285-97, ASTM Philadelphia, PA, (1998).

9. T.D. Chikalla, R.P. Turcotte, Rad. Eff. 19, 93-98 (1973).

10. T.C. Chikalla-73

11. S.M. Frank, K.J. Bateman, T. DiSanto, S.G. Johnson, T.L. Moschetti, M.H. Noy and T.P. O'Holleran, Phase Transformations and Systems Driven Far From Equilibrium, Eds., E. Ma, M. Atzmon, P. Bellon and R. Trivedi, Mat. Res. Soc. Symp. Proc. Vol. 481, pp. 351-356 (1998).

12. N.E. Bibler, J.K. Bates, Scientific Basis for Nuclear Waste Management XIII, Eds., V. Oversby and P. Brown, Mat. Res. Soc. Symp. Proc. Vol. 176, pp. 327-338 (1990). 